\title{
Effect of quantum dots on the biological behavior of the EJ human bladder urothelial carcinoma cell line
}

\author{
RUN YUAN*, WEI-MIN YU* , FAN CHENG, XIAO-BIN ZHANG, \\ YUAN RUAN, ZHI-XIU CAO and STÉPHANE LARRÉ \\ Department of Urology, Renmin Hospital of Wuhan University, \\ Wuhan, Hubei 430060, P.R. China
}

Received October 9, 2014; Accepted July 17, 2015

DOI: $10.3892 / \mathrm{mmr} .2015 .4174$

\begin{abstract}
Quantum dots (QDs) are a type of fluorescent label with applications in biological molecules, cells and in vivo imaging. The current study investigated the effect of QDs on the toxicity, proliferation, migration and invasion of the EJ human bladder cancer cell line in vitro. The cell counting kit- 8 test was used to measure the survival rate of EJ cells following incubation with varying concentrations of QDs. Additionally, the effect of QDs on tumor cell migration and invasion was evaluated using the Transwell chamber assay, and cell proliferation rate was assessed using a hemocytometer. Data from the current study demonstrated no significant differences in survival rate between the experimental and control groups with the conventionally used concentrations (5, 10 and $20 \mathrm{nM}$ ) of QD605 ( $\mathrm{P}>0.05)$. However, with high concentrations of QD605 (40 and $80 \mathrm{nM}$ ), significant differences were observed $(\mathrm{P}<0.001)$. The survival rate of EJ cells, however, remained at $92.6 \%$. In addition, no significant differences were observed between the EJ cells labeled with transactivator of transcription (TAT)-QD605 and the unlabeled EJ cells with regard to proliferation, migration and invasion $(\mathrm{P}>0.05)$. Thus, the results of the current study indicate that QDs exhibit a certain degree of influence on the activity of the EJ bladder cancer cell line at high concentrations. However, at the concentrations that QDs are conventionally used, there was little impact on the survival of the EJ cells. In addition, the proliferation, migration and invasion abilities of the EJ cells were not affected by TAT-QDs. Therefore, the peptide-conjugated QDs have potential to be applied in the imaging and tracking of live cells in vitro and of animals in vivo. Notably, QDs may provide the
\end{abstract}

Correspondence to: Dr Fan Cheng, Department of Urology, Renmin Hospital of Wuhan University, 238 Jiefang Road, Wuhan, Hubei 430060, P.R. China

E-mail: urology1969@aliyun.com

${ }^{*}$ Contributed equally

Key words: quantum dots, bladder urothelial carcinoma, peptide, biological behavior, migration, invasion foundation for a novel, non-invasive imaging strategy for the early diagnosis of tumors.

\section{Introduction}

Bladder cancer is associated with a high morbidity and mortality rate worldwide. Annually, 350,000 new cases are diagnosed and there are 15,000 cases of bladder cancer-associated mortality (1). In the United States, bladder cancer is the third most common malignant tumor in males and the tenth in females (2). Bladder urothelial carcinoma accounts for $\sim 90 \%$ of all cases of bladder cancer, $75-85 \%$ of which is classed as non-muscle invasive bladder urothelial cancer (NMIBUC), while the remainder is muscle invasive BUC (MIBUC) (3). Transurethral resection of bladder cancer combined with postoperative chemotherapy is the predominant therapeutic method to treat NMIBUC, which has a five-year survival rate of $85-90 \%(4,5)$. However, tumor recurrence occurs in $\leq 70 \%$ of postoperative patients and $20 \%$ of recurrent patients will progress to MIBUC, which has a high rate of metastasis and mortality $(4,5)$. Surgical technologies are improving, however when patients undergo radical cystectomy and systemic chemoradiotherapy, distant metastasis occurs in $~ 50 \%$ of the tumors within two years and the five-year mortality rate is $\leq 60 \%$ (6). Given the high recurrence and progressive rate of BUC, patients often require a lengthy and expensive follow-up (3). Thus, the early detection of superficial tumors that exhibit an infiltrating tendency, and invasive tumors with metastatic potential, is important for the development of therapeutic treatment strategies and establishing an accurate prognosis $(7,8)$.

Quantum dots (QDs) are luminescent semiconductor nanocrystals. QDs, a type of fluorescent label, are widely applied in the biological and biomedical fields due to their unique optical properties (9). Compared with traditional organic fluorescent probes, QDs possess a wide absorption spectra and a narrow emission peak for simultaneous excitation of multiple fluorescence colors, high fluorescence intensity, long fluorescent duration, stable fluorescence of long-term emission and strong resistance to photobleaching (9). Previous studies have demonstrated that QDs may be used in the labeling of live cells and cancer cells for animal imaging and tracking in vivo (10-13). QDs have demonstrated prognostic potential 
in the early diagnosis and targeted therapy of tumors (14-16). However, a key issue that currently requires a solution involves the toxicity and influence of QDs on the biological behavior of live cells. The current study aimed to investigate the effect of QDs (CdSe-ZnS) on the toxicity, proliferation, migration and invasion of the EJ human bladder cancer cell line in vitro. The results aimed to provide a theoretical basis for subsequent imaging and tracking studies in vivo and for the early diagnosis of bladder cancer.

\section{Materials and methods}

Materials and instruments. The EJ human bladder urothelial carcinoma cell line was donated by the Department Laboratory of Urology, Zhongnan Hospital of Wuhan University (Wuhan, China). The QD605 (CdSe-ZnS) Cell Tracing kit (QK605CT) was obtained from Wuhan Jiayuan Quantum Dots Co., Ltd., (Wuhan, China). The inverted fluorescence microscope was purchased from Olympus (IX71; Tokyo, Japan). Flow cytometry (FCM; CyAn ${ }^{\mathrm{TM}}$ ADP Analyzer, Beckman Coulter, Inc., Brea, CA, USA) was used for detecting the rate of cell labeling. The ELx800 Tecan Sunrise was purchased from BioTek Instruments, Inc., (Winooski, VT, USA). The Transwell chambers were from Corning Incorporated (Corning, NY, USA). Fetal bovine serum (FBS), RPMI-1640 and 0.25\% trypsin were purchased from GE Healthcare Life Sciences (Logan, UT, USA). The cell counting kit- 8 was purchased from Dojindo Molecular Technologies, Inc. (Kumamoto, Japan) and the Matrigel basement membrane matrix was obtained from BD Biosciences (Franklin Lakes, NJ, USA).

Cell culture. EJ cells were cultured in $250 \mathrm{ml}$ RPMI-1640 medium containing $10 \%$ FBS $(28 \mathrm{ml})$ and $1 \%$ penicillin-streptomycin ( $3 \mathrm{ml}$; Jenom, Hangzhou, China). When the cells reached $\geq 80 \%$ confluence, they were subcultured. The EJ cells were maintained at $37^{\circ} \mathrm{C}$ in a humidified $5 \% \mathrm{CO}_{2}$ atmosphere.

Detection of QD toxicity. Synchronously growing EJ cells were trypsinized with $0.25 \%$ trypsin and resuspended in RPMI-1640 medium, and inoculated into 96-well plates with $0.1 \mathrm{ml}$ $\left(1 \times 10^{4}\right.$ cells) per well. The EJ cells were then incubated at $37^{\circ} \mathrm{C}$ under a $5 \% \mathrm{CO}_{2}$ atmosphere for $24 \mathrm{~h}$. The cells were divided into three groups as follows: Control group, where $0.1 \mathrm{ml}$ RPMI-1640 medium was added; blank control group, where RPMI-1640 medium without cells or QD605 was added; and experimental group, where QD605 at concentrations of 5, 10, 20, 40 and $80 \mathrm{nM}$ was added (groups A-E, respectively). The control, blank, and experimental groups were set up in triplicate. Subsequent to culture for $24 \mathrm{~h}, 10 \mu \mathrm{l}$ cell counting kit- 8 was added directly to each well and the samples were incubated for an additional $2 \mathrm{~h}$. The ELx800 Tecan Sunrise was used to detect the optical density (OD) value of each well at a wavelength of $450 \mathrm{~nm}$. Finally, the survival rate of the tumor cells was calculated as follows: Survival rate $(\%)=($ Experimental group OD value - blank control group OD value)/(control group OD value - blank control group OD value) x 100. The experiment was repeated three times and means were calculated accordingly.

Fluorescent labeling of EJ cells with QDs and duration of fluorescence. Fluorescent labeling of EJ Cells with QD605 was conducted according to the manufacturer's instructions. The key steps were as follows: Exponentially growing EJ cells $\left(5 \times 10^{5}\right.$ cells $\left./ \mathrm{ml}\right)$ were inoculated onto a 12 -well plate. When the growth density was $~ 80 \%, 0.1 \mathrm{ml}$ QD605 labeling solution [10 $\mathrm{nM}$ transactivator of transcription (TAT)-QD605] was added to each well in the experimental group. The labeling solution was replaced by an equal volume of phosphate-buffered saline (PBS) in the control group. Each group had six equal wells. The cells were cultivated in an incubator at $37^{\circ} \mathrm{C}$ with $5 \% \mathrm{CO}_{2}$ for $1 \mathrm{~h}$, then the labeling solution was discarded and the cells were washed three times with PBS in order to remove the uncombined QDs. Subsequently, $0.5 \mathrm{ml}$ RPMI-1640 medium was added to each well and the samples were cultured for an additional $2 \mathrm{~h}$. The cells of three randomly selected wells were then resuspended in PBS following digestion with $0.25 \%$ trypsin and FCM was used to detect the labeling rate. The experiment was repeated three times and the mean labeling rate was determined. In addition, one randomly selected well in the experimental group was used to assess the fluorescent durability of QD605-labeled EJ cells.

Influence of QDs on cell growth. Synchronously growing EJ cells were seeded into four 24-well plates with $0.3 \mathrm{ml}$ ( $3 \times 10^{4}$ cells) per well. Following culture for $6 \mathrm{~h}$, the four plates were divided into four groups. For the control group, $0.05 \mathrm{ml}$ RPMI-1640 medium was added. For the experimental groups A-C, different final concentrations $(5,10$ and $20 \mathrm{nM}$, respectively) of QD605 labeling solution $(0.05 \mathrm{ml})$ diluted with RPMI-1640 medium were added. Each group was cultured for $1.5 \mathrm{~h}$, then $0.3 \mathrm{ml}$ RPMI-1640 medium was added to each well for continuous culture. After $2 \mathrm{~h}$, three wells of cells were randomly selected from each group for detecting the labeling rate of QDs by FCM. Detection of fluorescent labeling was conducted according to the above-mentioned method. Culture was continued for the remaining wells. The number of cells was counted in three randomly selected wells from each group. The cells were trypsinized into a single cell suspension and counted with a hemocytometer (XIE QIU JI SHU BAN; Shanghai Biochemical Reagent Refinement Instrument Co., Ltd., Shanghai, China). This was conducted over seven consecutive days. The cell growth curve was constructed according to the mean values obtained by cell counting.

Influence of QDs on cell migration. EJ cells were labeled with QD605 (10 $\mathrm{nM})$ according to the above-mentioned method and used for subsequent experiments. Two different methods were performed for assessing cell migration. For the Transwell assay, a Transwell chamber (Corning Incorporated) was used, which was separated into an upper and lower chamber by a polycarbonate membrane (pore diameter, $8 \mu \mathrm{m}$; Corning Incorporated). In the upper chamber, $0.2 \mathrm{ml} \mathrm{EJ/QD605} \mathrm{or}$ EJ cell suspension ( $5 \times 10^{4}$ cells) was added and in the lower chamber, $0.6 \mathrm{ml}$ RPMI-1640 medium containing 10\% FBS was added. The samples were incubated at $37^{\circ} \mathrm{C}$ under a $5 \% \mathrm{CO}_{2}$ atmosphere for $24 \mathrm{~h}$. Each group was set up in triplicate. The cells that migrated to the lower chamber below the polycarbonate membrane were stained with $0.2 \%$ crystal violet (Fortuneibo-tech Co., Ltd.) subsequent to fixing with formaldehyde (Goodbio-tech Co., Ltd, Wuhan, China). Five fields of 
visions (magnification, $\mathrm{x} 400$ ) were randomly selected and the number of cells in each field was counted using an Olympus IX71 microscope (Olympus Corporation, Tokyo, Japan).

The second method performed was the scratch assay. Synchronously-growing EJ/QD605 and EJ cells were inoculated into a 6 -well plate $\left(10^{5}\right.$ cells/well $)$, and each group was plated in triplicate. Following culture for $24 \mathrm{~h}$, the cell layer was scratched with a $10-\mu 1$ pipette tip, and the cells were washed three times with PBS in order to remove the detached cells. Serum-free RPMI-1640 medium (Jenom) was used for continuous culture. At 0 and $24 \mathrm{~h}$ subsequent to scratching, five fields of vision (magnification, x100; Olympus IX71 microscope) were randomly selected, and the width of the scratch was measured. The repair rate of the scratch was calculated as follows: Repair rate $(\%)=(0$-h width $-24 \mathrm{~h}$ width $) / 0 \mathrm{~h}$ width $\mathrm{x} 100$. The mean number of cells that had migrated and the mean repair rate of the scratches were considered to indicate the migratory capacity of the EJ/QD605 or EJ cells.

Influence of QDs on cell invasion. The cell invasion experiment was also conducted using Transwell assay. However, in contrast to the cell migration assay, the basement membrane was reconstructed using Matrigel:RPMI-1640 at a 1:8 ratio. A total of $40 \mu 1$ Matrigel that was diluted with serum-free RPMI-1640 (1:8) was added to the surface of each upper chamber membrane and allowed to set at $37^{\circ} \mathrm{C}$ for $1 \mathrm{~h}$. The Matrigel was then air-dried with ultraviolet irradiation overnight. To rehydrate the basement membrane, $0.2 \mathrm{ml}$ serum-free RPMI-1640 (1:8) was added and the plates were incubated for $1 \mathrm{~h}$ at $37^{\circ} \mathrm{C}$. Subsequently, $\mathrm{EJ} / \mathrm{QD} 605$ or EJ cells ( $3 \times 10^{5}$ cells) were added into the upper chamber, and all remaining steps were conducted using the same protocol as for the Transwell cell migration assay. Briefly, the cells that invaded to the lower chamber below the polycarbonate membrane were stained with $0.2 \%$ crystal violet (Fortuneibo-tech Co., Ltd., Shanghai, China) for $25 \mathrm{~min}$, prior to being fixed for $30 \mathrm{~min}$ with formaldehyde (Goodbio-tech Co., Ltd). The mean number of cells that had invaded to the chamber below the polycarbonate membrane was assessed to determine the invasive ability of EJ/QD605 or EJ cells.

Statistical analysis. All statistical analyses were performed with the SPSS 17.0 statistical package (SPSS, Inc., Chicago, IL, USA). The statistical differences between the groups were analyzed using Student's t-test. All experimental values are expressed as the mean \pm standard deviation. $\mathrm{P}<0.05$ was considered to indicate a statistically significant difference.

\section{Results}

High concentrations of $Q D$ s reduced the survival rate of $E J$ cells. Following $24 \mathrm{~h}$ of incubation with QDs, the survival rate of EJ cells declined as the concentration of QDs increased. The survival rate between the experimental group and control groups was not identified to be significantly different when the concentration of QDs used was 5, 10 or $20 \mathrm{nM}(\mathrm{P}>0.05)$; however, with 40 and $80 \mathrm{nM}$ QDs, significant differences were observed $(\mathrm{P}<0.001)$. The mean survival rate of the EJ cells remained high, at $95.7 \%$ and $92.6 \%$, with 40 and $80 \mathrm{nM}$ QDs respectively (Table I).
Table I. Survival rate of EJ cells at varying concentrations of QD605.

\begin{tabular}{lccr}
\hline & \multicolumn{2}{c}{ Survival rate, $\%$} & \\
\cline { 2 - 3 } $\begin{array}{c}\text { Concentration of } \\
\text { QDs, nM (n=27) }\end{array}$ & $\begin{array}{c}\text { Experimental } \\
\text { group }\end{array}$ & $\begin{array}{c}\text { Control } \\
\text { group }\end{array}$ & P-value \\
\hline 5 & $101 \pm 2.69$ & 100 & 0.062 \\
10 & $99.2 \pm 2.57$ & 100 & 0.092 \\
20 & $97.9 \pm 5.44$ & 100 & 0.055 \\
40 & $95.7 \pm 5.59$ & 100 & $<0.001$ \\
80 & $92.6 \pm 6.50$ & 100 & $<0.001$ \\
\hline
\end{tabular}

QD, quantum dot. The data are expressed as the mean \pm standard deviation.
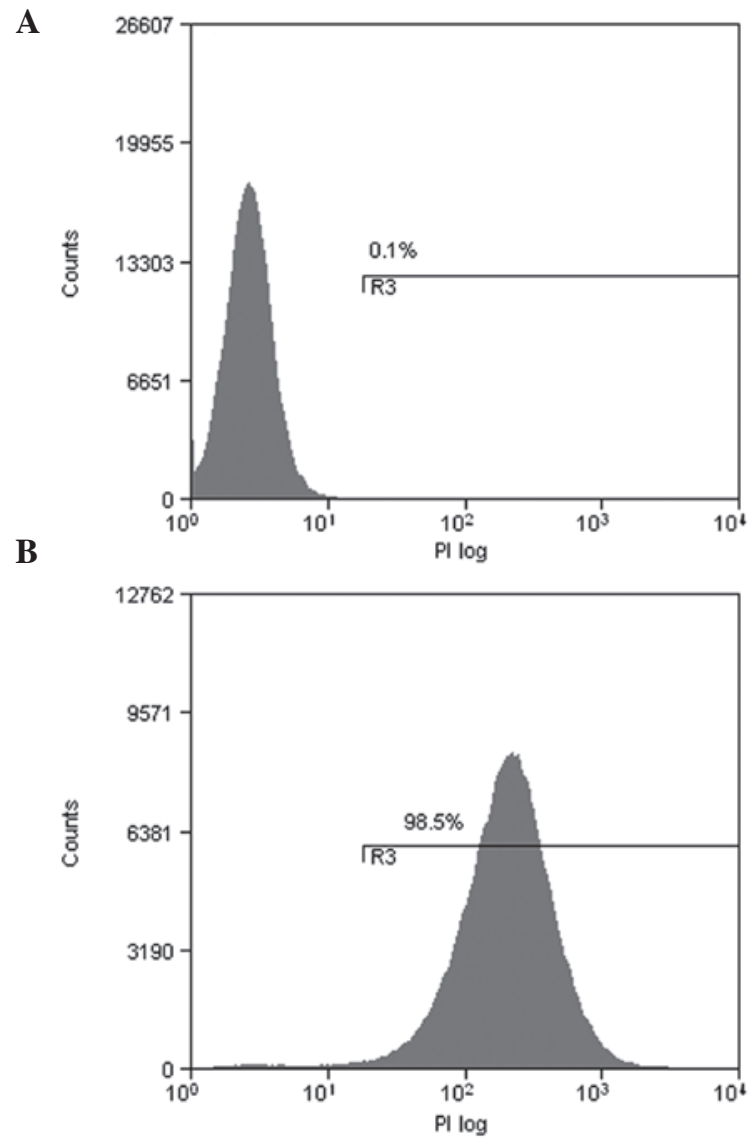

Figure 1. Flow cytometric detection of QD605 labeling of EJ cells for $2 \mathrm{~h}$. (A) Fluorescent labeling rate of the control group. (B) Fluorescent labeling rate of EJ cells with QD605. QD, quantum dot.

Labeling rate and durable fluorescence of EJ cells with $Q D s$. The fluorescence of traditional organic fluorescent materials decreases rapidly following excitation. However, the fluorescence of QDs continues to be emitted for a long time. The mean labeling rate of EJ cells following labeling for $2 \mathrm{~h}$ was $98.5 \%$ (Fig. 1). In line with cell proliferation over time, fluorescent intensity gradually reduced. Subsequent to labeling for 1 day, a large quantity of QD605 was present in the cytoplasm due to endocytosis (Fig. 2). 

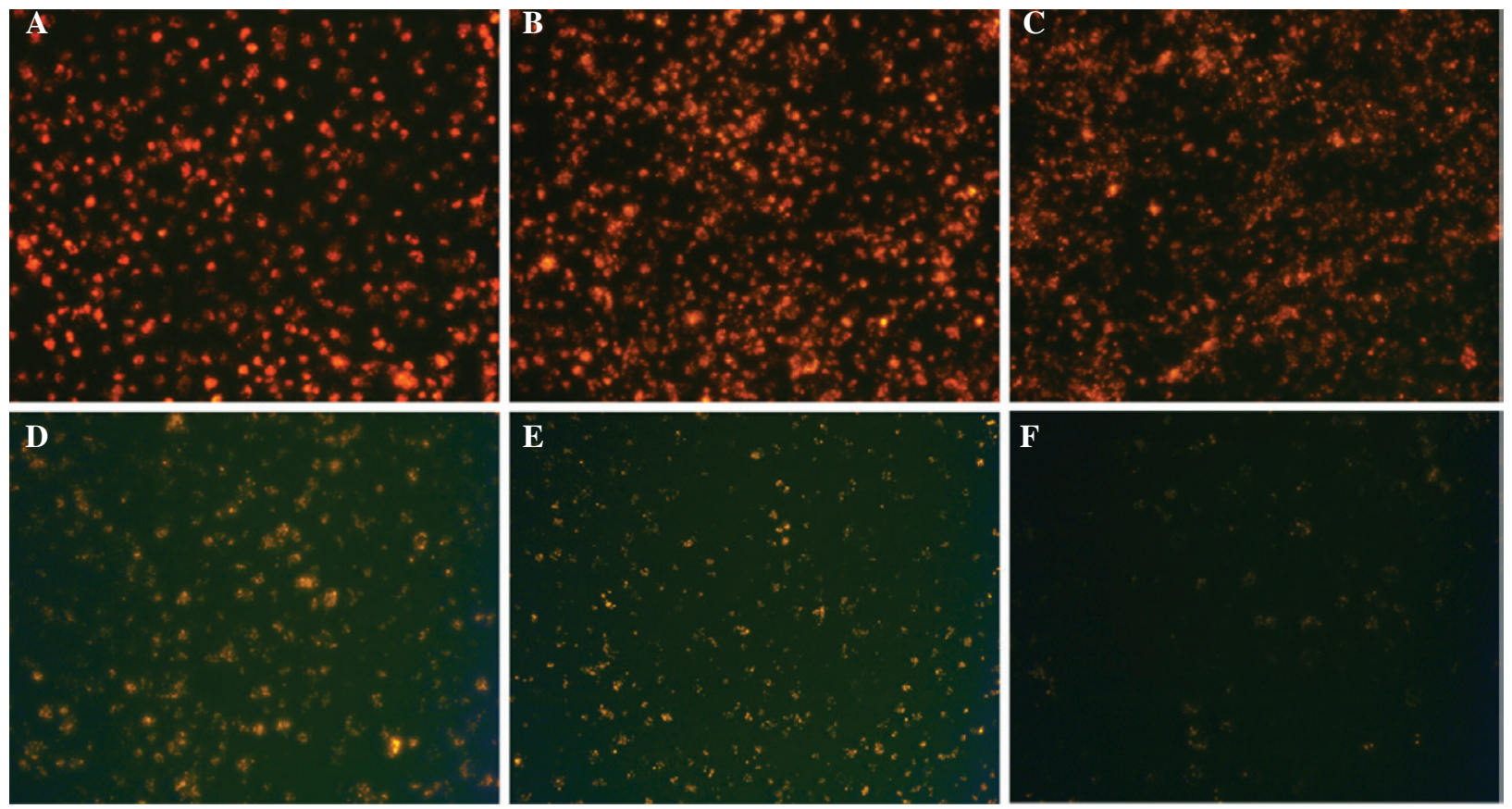

Figure 2. Fluorescent durability of EJ cells labeled with transactivator of transcription-quantum dot 605. (A-F) Alterations in fluorescent intensity during the week following subculture (which was conducted twice) at various time points. The cells were viewed under excitation with blue light. Magnification, x200.

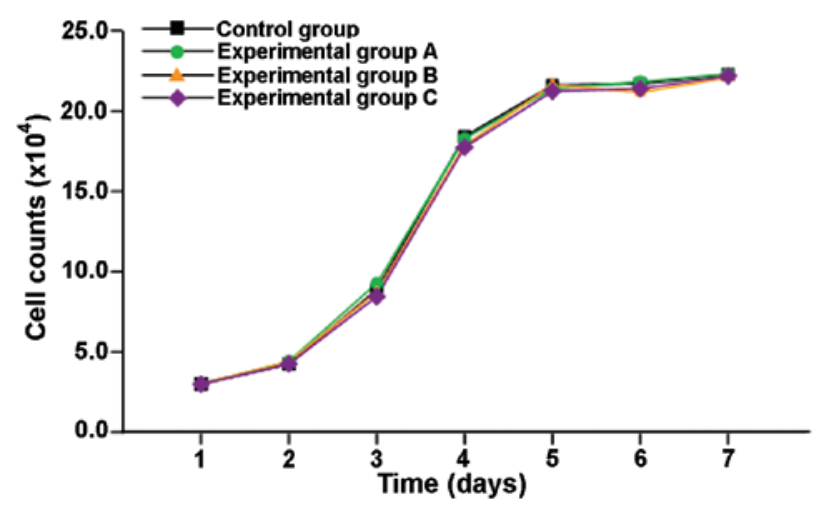

Figure 3. Growth curve of unlabeled EJ cells or EJ cells labeled with transactivator of transcription-quantum dot 605. Growth curve of EJ cells labeled with QD605 at final concentrations of (A) 5, (B) 10 and (C) $20 \mathrm{nM}$.
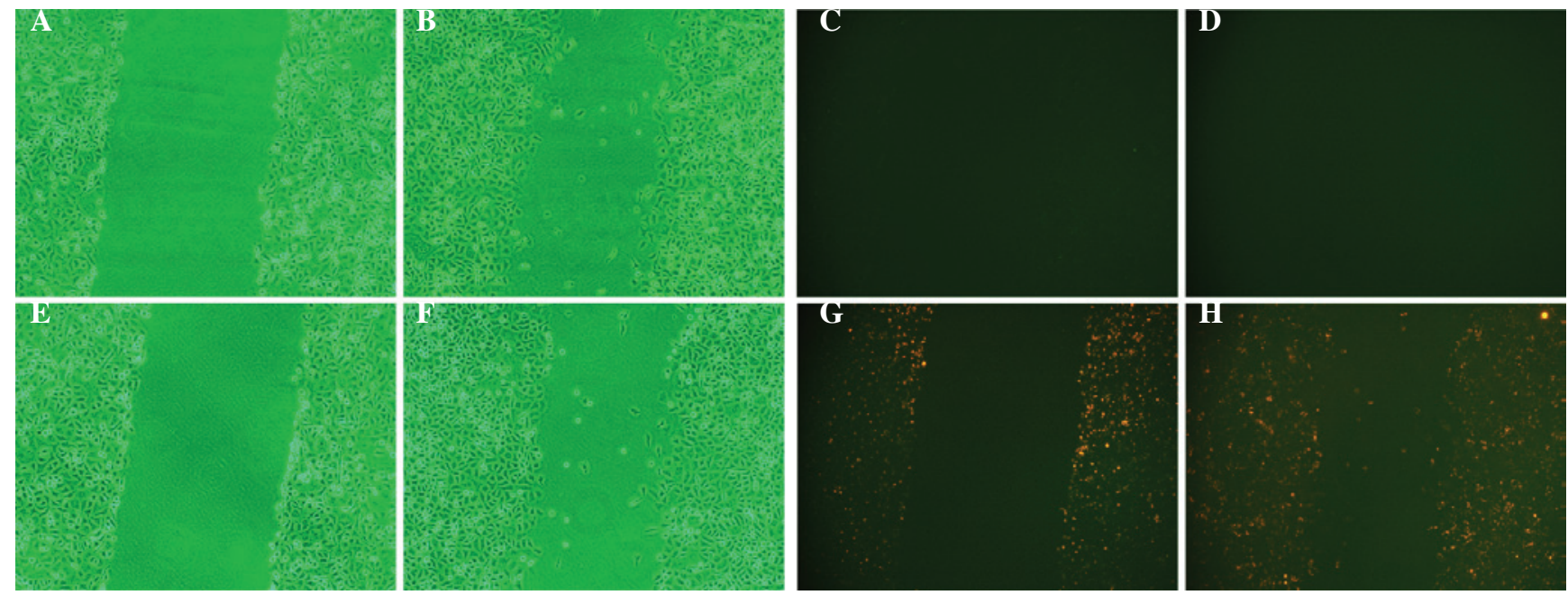

Figure 4. (A-D) Scratch width in the control group observed by (A and B) bright field microscopy and (C and D) by measuring excitation of blue light at (A and C) $0 \mathrm{~h}$ and (B and D) $24 \mathrm{~h}$. (E-H) Scratch width in the experimental group observed by (E and F) bright field microscopy and (G and $\mathrm{H}$ ) by measuring excitation of blue light at $(\mathrm{E}$ and $\mathrm{G}) 0 \mathrm{~h}$ and $(\mathrm{F}$ and $\mathrm{H}) 24 \mathrm{~h}$. Magnification, x100. 


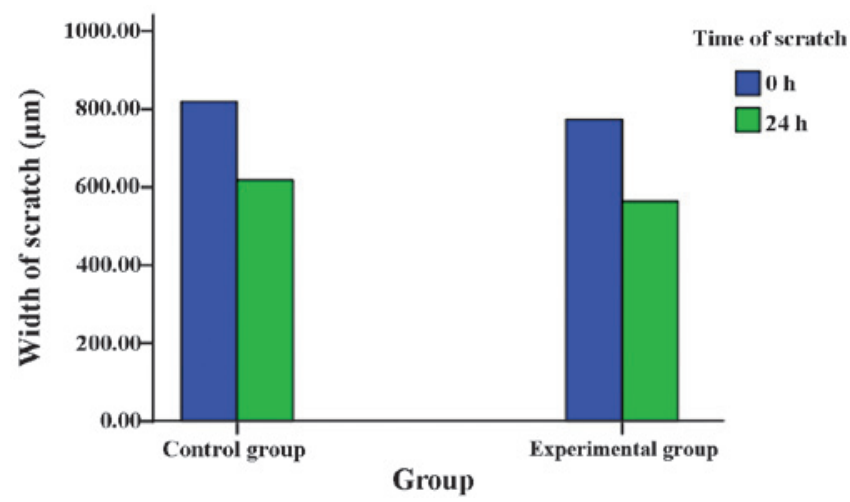

Figure 5. Scratch width at 0 and $24 \mathrm{~h}$ in the control and experimental groups.

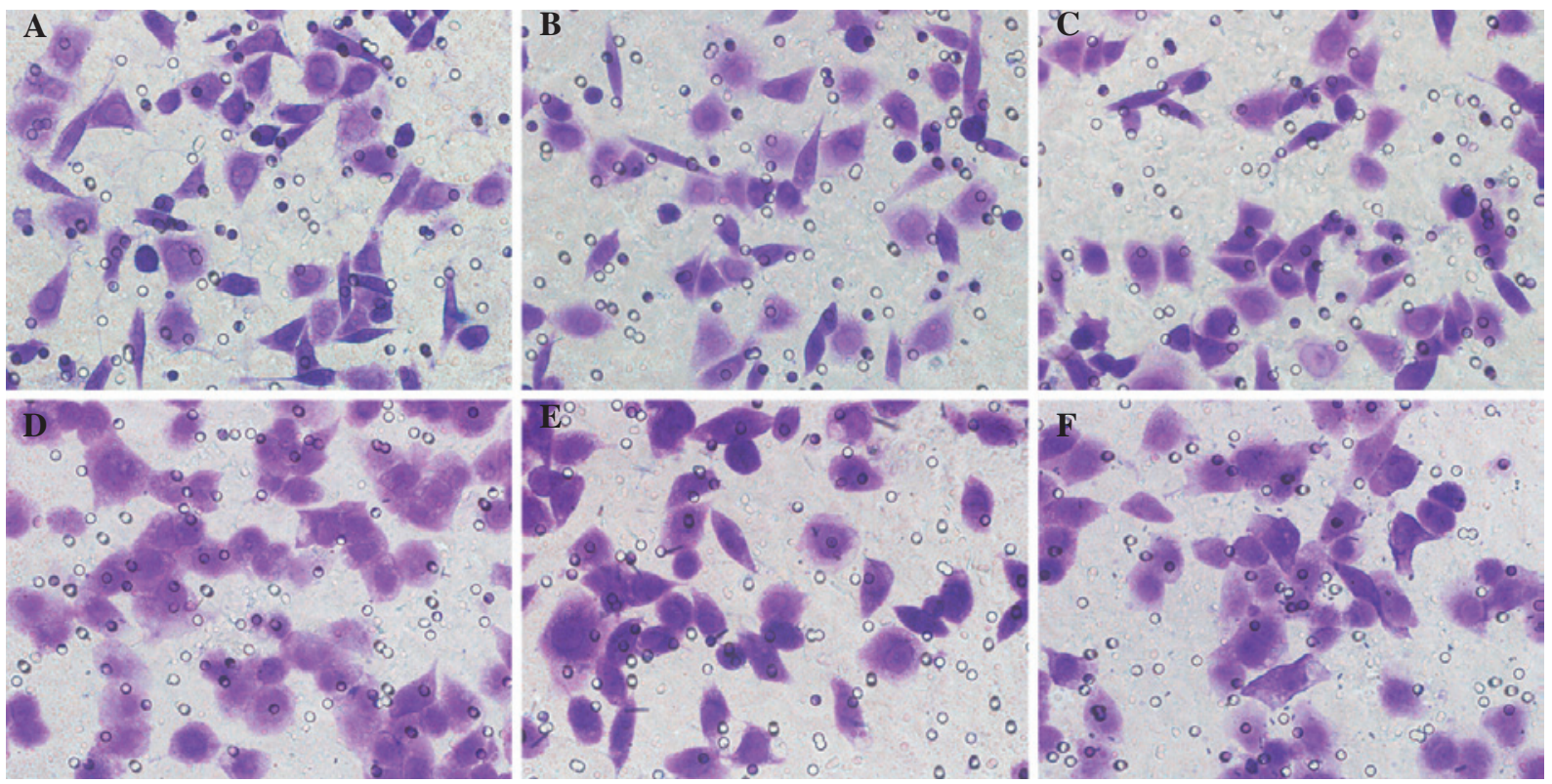

Figure 6. Migratory ability of the cells, as determined by the Transwell assay. The EJ cells that had penetrated the polycarbonate in the (A-C) control group (unlabeled EJ cells) and (D-F) experimental group (EJ cells labeled with transactivator of transcription-quantum dot 605). Magnification, x400.
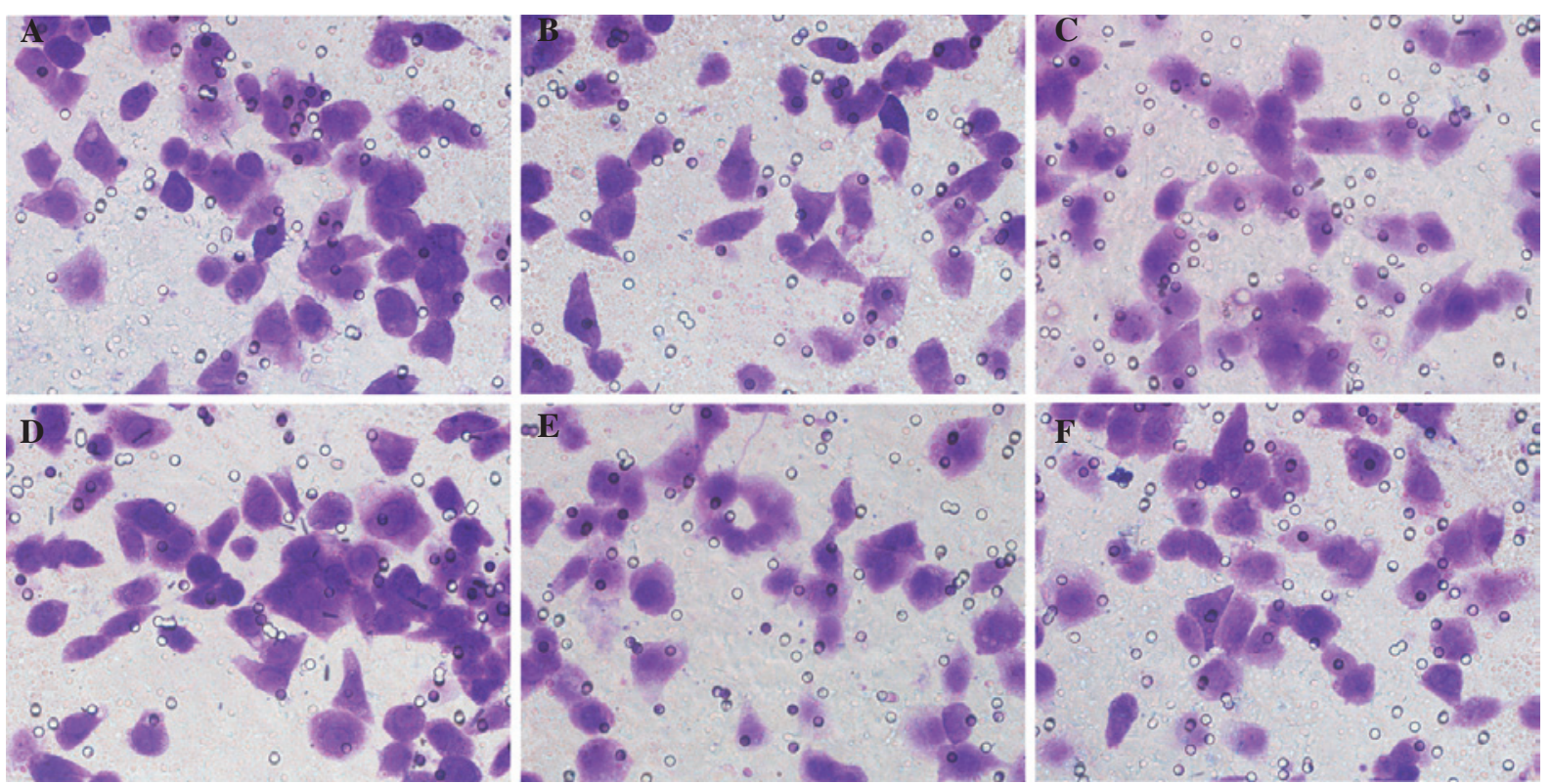

Figure 7. Invasive ability of the cells, as determined by the Transwell assay. The EJ cells that had penetrated through the Matrigel in the (A-C) control group (unlabeled EJ cells) and (D-F) experimental group (EJ cells labeled with transactivator of transcription-quantum dot 605). Magnification, x400. 
$Q D$ s exhibited no significant effect on the proliferation of EJ cells. The growth curves of unlabeled EJ cells or EJ cells labeled with different concentrations (5, 10 and $20 \mathrm{nM}$ ) of TAT-QD605 are presented in Fig. 3. The results demonstrate no significant differences between the growth curves of EJ/QD605 and EJ cells, indicating that the presence of TAT-QDs in the cytoplasm does not affect the growth of EJ cells.

QDs exhibited no significant effect on EJ cell migration. Two methods were performed to detect the effect of QDs on EJ cell migration. In the Transwell assay, the mean number of EJ/QD605 and EJ cells that penetrated the polycarbonate membrane without Matrigel was $50.13 \pm 1.41$ and $49.87 \pm 1.49$, respectively. Statistical analysis identified no significant difference between the number of QD605-labeled EJ cells and unlabeled EJ cells that had migrated $(\mathrm{P}>0.05)$. In the scratch test, the repair rate of the scratch in EJ/QD605 and EJ cells was $27.03 \pm 1.32 \%$ and $24.43 \pm 1.17 \%$, respectively, and there was no significant difference between QD605-labeled and unlabeled EJ cells $(\mathrm{P}>0.05)$. The two assays indicated that the labeling of EJ cells with QDs does not affect their migratory ability (Figs. 4-6).

$Q D$ s exhibited no significant effect on EJ cell invasion. The Matrigel on the surface of the upper chamber membrane served as an artificial basement membrane. In this assay, the tumor cells are required to degrade the matrix to invade, thus mimicking metastasis. Thus, the ability of a cell to penetrate through Matrigel indirectly reflects its invasive capability. The results collected demonstrated that the mean number of EJ/QD605 and EJ cells that penetrated the membrane was $41.47 \pm 0.88$ and $40.53 \pm 1.10$, respectively. The invasive capacity of the QD-labeled EJ cells and unlabeled EJ cells was not significantly different $(\mathrm{P}>0.05)$, suggesting that the labeling of EJ cells with QDs does not affect their invasive ability (Fig. 7).

\section{Discussion}

QDs are luminescent semiconductor nanocrystals with unique fluorescent properties (9). Compared with the traditional organic fluorescent materials, such as fluorescein isothiocyanate, Cy3 and Cy5, QDs have 10-20 times greater fluorescence intensity and their fluorescence durability is 100-1,000 times that of organic fluorescence (17). In addition, the emission wavelength of QDs can be adjusted by changing the size and composition of the QDs, and the emission spectrum ranges from visible light to infrared light. Thus, fluorescent labeling imaging of deep tissues can be performed in vitro using near infrared or infrared photon imaging (18). Additionally, QDs have a wide absorption spectrum and narrow emission peak, thus enabling simultaneous imaging of multiple molecules (19-21).

QDs have a broad range of potential applications in cell labeling, imaging, tracking in vivo and monitoring biological macromolecular interactions due to their optical properties (9). A non-invasive in vivo study indicated that there may be potential for the use of QDs in the development and early diagnosis of cancer and the transfer process of therapeutic agents (22). However, the application of QDs is limited in biological and biomedical fields due to their toxicity towards cells, solubility in water and ability to penetrate cell membranes. Research advancements have enabled the modification of the surface of QDs with different molecules, in order to reduce their cytotoxicity, increase their water solubility and improve their ability to penetrate cell membranes. These properties are of great importance in intracellular imaging, tracing and drug targeting transport. Dubertret et al (23) used modified QDs during the development of clawed frog embryo cells and identified that QDs exerted no influence on cell growth, development, migration, signal transduction and other physiological activities. Mattheakis et al (24) and Pinaud et al (25) fluorescently labeled normal mammalian cells with QDs that exhibited wrapped inner cores. The cells were incubated for 2 weeks, and there was no apparent difference between the growth of the QD-labeled and unlabeled cells.

In the current study, the cytotoxicity of different concentrations of QD605 (CdSe-ZnS) was assessed in EJ cells. The viability of EJ cells was marginally reduced with increasing concentrations of QD605, however the reduction was not significant. At the high concentration $(80 \mathrm{nM})$, the survival rate of EJ cells remained high (92.6\%). At conventionally used concentrations $(5,10$ and $20 \mathrm{nM}$ QD605), the survival rate was not significantly different between the experimental and control groups.

Cell-penetrating peptides (CPPs) are short peptides with $<20$ amino acids and a positive charge $(26,27)$. They function in transmembrane transduction and are able to pass through the majority of the cellular membrane without resulting in cellular injury. TAT protein is the $48-60$ polypeptide fragment of the human immunodeficiency virus-1 and was the first CPP to be discovered. It has been widely used in the delivery of extracellular bioactive molecules, including small interfering RNA (28-30), nucleic acids $(31,32)$, proteins $(33,34)$ and QDs (35), into cells (36). Previous studies have demonstrated that the modification of the surface of QDs with CPPs improves the labeling rate of cells $(37,38)$. Xue et al (39) developed sulfhydryl-modified QDs combined with the TAT protein to obtain TAT-QD compounds. The QGY liver cancer and the MCF-7 human breast cancer cell lines were cultivated with TAT-QDs and these cells were assessed by laser confocal scanning microscopy (39). The penetration of TAT-QDs into the QGY and MCF-7 cells was observed to increase compared with unmodified QDs, by 2.1 and 1.5 times, respectively. In addition, compared with alternative delivery methods, this method was observed to exhibit a lower level of cytotoxicity in all cell lines examined (40).

Few studies have focused upon the effect of TAT-conjugated QDs on the proliferation, migration and invasion of cancer cells, thus investigation of this will be beneficial for future non-invasive and visual studies of cancer in vivo with CPPs. In the current study, the co-culture of TAT-QD605 with EJ cells resulted in the rapid entry of QD605 into the cytoplasm, and the mean fluorescent labeling rate of EJ cells increased to $98.4 \%$ subsequent to $2 \mathrm{~h}$ of culture. The intracellular TAT-QD605 did not affect the proliferation, migration and invasion of EJ cells. These results demonstrate that peptide-conjugated QDs have potential for application in labeling, imaging and tracking of live cells in vitro and in animals in vivo, as well as for investigation of tumor development and early diagnosis. 


\section{Acknowledgements}

The authors would like to thank Professor Dai-Wen Pang and Dr. Jun Peng (College of Chemistry and Molecular Sciences and State Key Laboratory of Virology of Wuhan University, Wuhan, China) for his technical assistance in the current study. The present study was supported by grants from the National Natural Science Foundation of China (grant no. 81272826).

\section{References}

1. Ferlay J, Shin HR, Bray F, Forman D, Mathers C and Parkin DM Estimates of worldwide burden of cancer in 2008: GLOBOCAN 2008. Int J Cancer 127: 2893-2917, 2010.

2. Siegel R, Naishadham D and Jemal A: Cancer statistics, 2013. CA A Cancer J Clin 63: 11-30, 2013

3. Babjuk M, Oosterlinck W, Sylvester R, Kaasinen E, Böhle A, Palou-Redorta J, Rouprêt $M$ and European Association of Urology (EAU): EAU guidelines on non-muscle-invasive urothelial carcinoma of the bladder, the 2011 update. Eur Urol 59: 997-1008, 2011.

4. Milowsky MI, Stadler WM and Bajorin DF: Integration of neoadjuvant and adjuvant chemotherapy and cystectomy in the treatment of muscle-invasive bladder cancer. BJU Int 102: 1339-1344, 2008.

5. Stein JP, Lieskovsky G, Cote R, Groshen S, Feng AC, Boyd S, Skinner E, Bochner B, Thangathurai D, Mikhail M, et al: Radical cystectomy in the treatment of invasive bladder cancer: Long-term results in 1,054 patients. J Clin Oncol 19: 666-675, 2001.

6. Shariat SF, Karakiewicz PI, Palapattu GS, Lotan Y, Rogers CG Amiel GE, Vazina A, Gupta A, Bastian PJ, Sagalowsky AI, et al: Outcomes of radical cystectomy for transitional cell carcinoma of the bladder: A contemporary series from the bladder cancer research consortium. J Urol 176: 2414-2422, 2006.

7. Yu RJ, Stein JP and Cai J, Miranda G, Groshen S and Skinner DG: Superficial (pT2a) and deep (pT2b) muscle invasion in pathological staging of bladder cancer following radical cystectomy. J Urol 176: 493-498, 2006.

8. Nieder AM, Simon MA, Kim SS, Manoharan M and Soloway MS: Radical cystectomy after bacillus Calmette-Guérin for high-risk $\mathrm{Ta}, \mathrm{T} 1$ and carcinoma in situ: Defining the risk of initial bladder preservation. Urology 67: 737-741, 2006.

9. Yu WW, Chang E, Drezek R and Colvin VL: Water-soluble quantum dots for biomedical applications. Biochem Biophys Res Commun 348: 781-786, 2006.

10. Larson DR, Zipfel WR, Williams RM, Clark SW, Bruchez MP, Wise FW and Webb WW: Water-soluble quantum dots for multiphoton fluorescence imaging in vivo. Science 300: 1434-1436, 2003.

11. Akerman ME, Chan WC, Laakkonen P, Bhatia SN and Ruoslahti E: Nanocrystal targeting in vivo. Proc Natl Acad Sci USA 99: 12617-12621, 2002.

12. Algar WR, Tavares AJ and Krull UJ: Beyond labels: A review of the application of quantum dots as integrated components of assays, bioprobes, and biosensors utilizing optical transduction. Anal Chim Acta 673: 1-25, 2010.

13. Rosenthal SJ, Chang JC, Kovtun O, McBride JR and Tomlinson ID: Biocompatible quantum dots for biological applications. Chem Biol 18: 10-24, 2011.

14. Michalet X, Pinaud FF, Bentolila LA, Tsay JM, Doose S, Li JJ, Sundaresan G, Wu AM, Gambhir SS and Weiss S: Quantum dots for live cells, in vivo imaging, and diagnostics. Science 307: 538-544, 2005.

15. Geissler D, Charbonnière LJ, Ziessel RF, Butlin NG, Löhmannsröben HG and Hildebrandt N: Quantum dot biosensors for ultrasensitive multiplexed diagnostics. Angew Chem Int Ed Engl 49: 1396-1401, 2010

16. Medintz IL, Uyeda HT, Goldman ER and Mattoussi H: Quantum dot bioconjugates for imaging, labelling and sensing. Nat Mater 4: 435-446, 2005.

17. Gao X, Cui Y, Levenson RM, Chung LW and Nie S: In vivo cancer targeting and imaging with semiconductor quantum dots Nat Biotechnol 22, 969-976, 2004

18. Smith AM, Ruan G, Rhyner MN and Nie S: Engineering luminescent quantum dots for in vivo molecular and cellular imaging. Ann Biomed Eng 34: 3-14, 2006.
19. Baiiey RE and Nie SM: Alloyed semiconductor guantum dots:Tuning the optical properties without changing the particle size. J Am Chem Soc 125: 7100-7106, 2003.

20. Han M, Gao X, Jack Z, Su JZ and Nie S: Quantum-dot-tagged microbeads for multiplexed optical coding of biomolecules. Nat Biotechnol 19: 631-635, 2001.

21. Wehrenberg BL, Wang CJ and Philippe GS: Interband and intraband optical studies of PbSe colloidal quantum dots. J Phys Chem B 106: 10634-10640, 2002.

22. Mattoussi H, Palui G and Na HB: Luminescent quantum dots as platforms for probing in vitro and in vivo biological processes. Adv Drug Deliv Rev 64: 138-166, 2012.

23. Dubertret B, Skourides P, Norris DJ, Noireaux V, Brivanlou $\mathrm{AH}$ and Libchaber A: In vivo imaging of quantum dots encapsulated in phospholipid micelles. Science 298: 1759-1762, 2002.

24. Mattheakis LC, Dias JM, Choi YJ, Gong J, Bruchez MP, Liu J and Wang E: Optical coding of mammalian cells using semiconductor quantum dots. Anal Biochem 327: 200-208, 2004.

25. Pinaud F, King D, Moore HP and Weiss S: Bioactivation and cell targeting of semiconductor $\mathrm{CdSe} / \mathrm{ZnS}$ nanocrystals with phytochelatin-related peptides. J Am Chem Soc 126: 6115-6123, 2004

26. Jiang T, Zhang Z, Zhang Y, Lv H, Zhou J, Li C, Hou L and Zhang Q: Dual-functional liposomes based on $\mathrm{pH}$-responsive cell-penetrating peptide and hyaluronic acid for tumor-targeted anticancer drug delivery. Biomaterials 33: 9246-9258, 2012.

27. Milletti F: Cell-penetrating peptides: Classes, origin, and current landscape. Drug Discov Today 17: 850-860, 2012.

28. Nakase I, Tanaka G and Futaki S: Cell-penetrating peptides (CPPs) as a vector for the delivery of siRNAs into cells. Mol Biosyst 9: 855-861, 2013.

29. Cheng CJ and Saltzman WM: Enhanced siRNA delivery into cells by exploiting the synergy between targeting ligands and cell-penetrating peptides. Biomaterials 32: 6194-6203, 2011.

30. Ezzat K, Zaghloul EM, El Andaloussi S, Lehto T, El-Sayed R, Magdy T, Smith CI and Langel U: Solid formulation of cell-penetrating peptide nanocomplexes with siRNA and their stability in simulated gastric conditions. J Control Release 162: $1-8,2012$

31. Bai H, You Y, Yan H, Meng J, Xue X, Hou Z, Zhou Y, Ma X, Sang G and Luo X: Antisense inhibition of gene expression and growth in gram-negative bacteria by cell-penetrating peptide conjugates of peptide nucleic acids targeted to rpoD gene. Biomaterials 33: 659-667, 2012.

32. Nakase I, Akita H, Kogure K, Gräslund A, Langel U, Harashima H and Futaki S: Efficient intracellular delivery of nucleic acid pharmaceuticals using cell-penetrating peptides. Acc Chem Res 45: $1132-1139,2012$

33. Liu BR, Liou JS, Chen YJ, Huang YW and Lee HJ: Delivery of nucleic acids, proteins, and nanoparticles by arginine-rich cell-penetrating peptides in rotifers. Mar Biotechnol (NY) 15: 584-595, 2013

34. Liu BR, Huang YW and Lee HJ: Mechanistic studies of intracellular delivery of proteins by cell-penetrating peptides in cyanobacteria. BMC Microbiol 13: 57, 2013.

35. Santra S, Yang H, Stanley JT, Holloway PH, Moudgil BM, Walter G and Mericle RA: Rapid and effective labeling of brain tissue using TAT-conjugated CdS: $\mathrm{Mn} / \mathrm{ZnS}$ quantum dots. Chem Commun (Camb) 3144-3146: 2005.

36. Hyndman L, Lemoine JL, Huang L, Porteous DJ, Boyd AC and Nan X: HIV-1 Tat protein transduction domain peptide facilitates gene transfer in combination with Cationic liposomes. J Control Release 99: 435-444, 2004.

37. Chen B, Liu Q, Zhang Y, Xu L and Fang X: Transmembrane delivery of the cell-penetrating peptide conjugated semiconductor quantum dots. Langmuir 24: 11866-11871, 2008.

38. Lei Y, Tang H, Yao L, Yu R, Feng M and Zou B: Applications of mesenchymal stem cells labeled with Tat peptide conjugated quantum dots to cell tracking in mouse body. Bioconjug Chem 19: 421-427, 2008.

39. Xue FL, Chen JY, Guo J, Wang CC, Yang WL, Wang PN and Lu DR: Enhancement of intracellular delivery of CdTe quantum dots (QDs) to living cells by tat conjugation. J Fluoresc 17: 149-154, 2007.

40. Vives E, Schmidt J and Pèlegrin A: Cell-penetrating and cell-targeting peptides in drug delivery. Biochim Biophys Acta 1786: 126-138, 2008. 